\title{
Fabrication and Characterization of Mullite Reinforced CaO Added $\mathrm{ZrO}_{2}$ Ceramics
}

\author{
Mehmet Akif Hafizoğlu ${ }^{1 *}$, Ahmet Akkuş ${ }^{2}$, Tahsin Boyraz ${ }^{3}$ \\ ${ }^{1 *}$ Sivas Cumhuriyet University, Faculty of Engineering, Department of Mechanical Engineering, Sivas, Turkey, (ORCID: 0000-0002-9689-3004), \\ mehmedhaf@hotmail.com \\ ${ }^{2}$ Sivas Cumhuriyet University, Faculty of Engineering, Department of Mechanical Engineering, Sivas, Turkey, (ORCID: 0000-0002-6881-9333), \\ aakkus@cumhuriyet.edu.tr \\ ${ }^{3}$ Sivas Cumhuriyet University, Faculty of Engineering, Department of Metallurgical and Materials Engineering, Sivas, Turkey, (ORCID: 0000-0003-4404-6388), \\ tahsinboyraz@,cumhuriyet.edu.tr
}

(1st International Conference on Applied Engineering and Natural Sciences ICAENS 2021, November 1-3, 2021)

(DOI: 10.31590/ejosat.1013434)

ATIF/REFERENCE: Hafızoğlu, M. A., Akkuş, A. \& Boyraz, T. (2021). Fabrication and Characterization of Mullite Reinforced CaO Added $\mathrm{ZrO}_{2}$ Ceramics. European Journal of Science and Technology, (28), 1137-1143.

\begin{abstract}
In this study, mullite $\left(3 \mathrm{Al}_{2} \mathrm{O}_{3} \cdot 2 \mathrm{SiO}_{2}\right)$ and $11 \mathrm{~mol} \%$ calcia added zirconia $\left(11 \mathrm{~mol} \% \mathrm{CaO}-89 \mathrm{~mol} \% \mathrm{ZrO}_{2}\right)$ ceramic powders were synthesized by conventional ceramic production processing route. The mixtures were prepared by mechanical alloying method in acetone environment with zirconia ball mill. The powders were dried in oven at $110{ }^{\circ} \mathrm{C}$ for 24 hours before mixing. Mullite $\left(3 \mathrm{Al}_{2} \mathrm{O}_{3} \cdot 2 \mathrm{SiO}_{2}\right)$ and $11 \mathrm{~mol} \%$ calcia added zirconia $\left(\mathrm{CaO}-\mathrm{ZrO}_{2}\right)$ ceramic powders were synthesized by reaction sintering from the powders made up of stoichiometric proportions of $\mathrm{Al}_{2} \mathrm{O}_{3}, \mathrm{SiO}_{2}, \mathrm{CaO}$ and $\mathrm{ZrO}_{2}$ powders after being homogenized in acetone environment in ball mills. Mullite $\left(3 \mathrm{Al}_{2} \mathrm{O}_{3} \cdot 2 \mathrm{SiO}_{2}\right)$ and $11 \mathrm{~mol} \%$ calcia added zirconia $\left(\mathrm{CaO}-\mathrm{ZrO}_{2}\right)$ ceramic powders were synthesized in air at 1600 ${ }^{\circ} \mathrm{C}$ for $3 \mathrm{~h}$ and $1300{ }^{\circ} \mathrm{C}$ for $2 \mathrm{~h}$, respectively. Then, the ceramic phases formed were made ready to form ceramic - ceramic composites by crushing, grinding and sieving processes. Then 0 and $10 \%$ by weight mullite $(\mathrm{M})$ added calcia doped zirconia (CaZ) mixtures were prepared by powder metallurgy method. The prepared mixtures were wet milled with zirconia ball mill for $24 \mathrm{~h}$ and sieved. After drying, the powders were compacted to preforms of $56 \times 12 \times 10 \mathrm{~mm}$ by uniaxial pressing at $200 \mathrm{MPa}$. The green compacts were sintered at 1500 $1600{ }^{\circ} \mathrm{C}$ for $1-5 \mathrm{~h}$ in air conditions using a heating rate of $5^{\circ} \mathrm{C}$ min-1 in a high temperature furnace. Then, microstructure (SEM), phase analysis (XRD), mechanical (hardness, 3-point bending and wear) and physical properties (\% shrinkage, water absorption, porosity and density) tests were performed on the mullite added calcia doped zirconia ceramic composites. In this study, whether there is a phase change in the $\mathrm{ZrO}_{2}-\mathrm{CaO}$ mixture at high sintering temperatures and the effect of mullite additive on the properties of this mixture was investigated. The data obtained were presented in graphs and tables and their comments were made.
\end{abstract}

Keywords: Zirconia, Mullite, Calcia, Characterization, Wear.

\section{Mullit Takviyeli $\mathrm{CaO}$ Katkılı $\mathrm{ZrO}_{2}$ Seramiklerinin İmalatı ve Karakterizasyonu}

$\ddot{O} z$

$\mathrm{Bu}$ çalışmada, mullit $\left(3 \mathrm{Al}_{2} \mathrm{O}_{3} \cdot 2 \mathrm{SiO}_{2}\right)$ ve $\% 11 \mathrm{~mol}$ kalsiyum oksit katkılı zirkonya $\left(\% 11 \mathrm{~mol} \mathrm{CaO}-\% 89\right.$ mol $\left.\mathrm{ZrO}_{2}\right)$ seramik tozları geleneksel seramik üretim yöntemi ile sentezlenmiştir. Karışımlar, zirkonya bilyalı değirmende aseton ortamında mekanik alaşımlama yöntemiyle hazırlanmıştır. Tozlar karıştırılmadan önce $110^{\circ} \mathrm{C}$ 'de 24 saat etüvde kurutulmuştur. $\mathrm{Al}_{2} \mathrm{O}_{3}, \mathrm{SiO}_{2}, \mathrm{CaO}$ ve $\mathrm{ZrO}_{2}$ tozlarının stokiyometrik oranlarından oluşan tozların aseton ortamında bilyeli değirmende homojenize edildikten sonra geleneksel sinterleme yöntemiyle Mullit $\left(3 \mathrm{Al}_{2} \mathrm{O}_{3} \cdot 2 \mathrm{SiO}_{2}\right)$ ve $\% 11$ mol kalsiyum oksit katkılı zirkonya $\left(\mathrm{CaO}-\mathrm{ZrO}_{2}\right)$ seramik tozları sentezlenmiştir. Mullit ve $\% 11$ mol kalsiyum oksit katkılı zirkonya seramik tozları sırasıyla $1600{ }^{\circ} \mathrm{C}^{\prime} \mathrm{de} 3$ saat ve $1300{ }^{\circ} \mathrm{C}$ de 2 saat sentezlenmiştir. Daha sonra oluşan seramik fazlar kırma, öğ̈̈tme ve eleme işlemleri ile seramik - seramik kompozitleri oluşturmaya hazır hale getirilmiştir. Daha sonra ağırlıç̧a \%0 ve \%10 mullit (M) takviyeli kalsiyum oksit katkılı zirkonya (CaZ) karışımları toz metalurjisi yöntemiyle hazırlanmıştır. Hazırlanan karışımlar zirkonya bilyalı değirmende 24 saat yaş öğütülmüş ve elenmiştir. Kurutulduktan sonra, tozlar 200 MPa'da tek eksenli presleme ile 56x12x10 mm'lik preformlara sıkıştırılmıştır. Devamında, yüksek sıcaklıklı bir firında $5{ }^{\circ} \mathrm{C} / \mathrm{dak}$ 1sıtma hızı kullanılarak hava koşullarında 1500-1600 oC'de 1-5 saat sinterlenmiştir. Daha sonra mullit takviyeli kalsiyum oksit katkılı zirkonya seramik kompozitler üzerinde mikroyapı (SEM), faz analizi (XRD), mekanik (sertlik, 3 nokta eğme ve aşınma) ve fiziksel özellikler (\% küçülme, su emme, gözeneklilik ve yoğunluk) testleri yapılmıştır. Bu çalışmada, yüksek sinterleme sıcaklıklarında $\mathrm{ZrO} 2$ karışımında faz değişimi olup olmadığı ve mullit katkı maddesinin bu karışımın özelliklerine etkisi araştırılmıştır. Elde edilen veriler grafik ve tablolar halinde sunulmuş ve yorumları yapılmıştır.

Anahtar Kelimeler: Zirkonya, Mullit, Kalsiyum oksit, Karakterizasyon, Aşınma.

* Corresponding Author: mehmedhaf@hotmail.com 


\section{Introduction}

Ceramic materials as a high temperature structural material due to their several interesting features such as, excellent resistance to heat, corrosion and abrasion, are preferred, in numerous areas like, cutting tools, extrusion dies, adiabatic diesel engine compartments [1-3]. However, ceramic materials have many disadvantages, such as low impact strength and fracture toughness, fragility and limited processability. So, a lot of studies focus on these issues to improve the structural and mechanical properties of ceramics. Among ceramic materials, zirconia $\left(\mathrm{ZrO}_{2}\right)$ and its composites have recently become the focus of scientific and technological studies because of their better mechanical properties, corrosion resistance, high temperature stability, low thermal conductivity and high chemical stability. [1]. They are used as structural materials in the manufacture of refractory crucibles for melting pure metals, components of furnaces, engines, heat barriers, wear resistant components, blade cutting tools and wire mesh drawing machines, dental studies and other a lot of fields [1-4]. High-purity zirconia $\left(\mathrm{ZrO}_{2}\right)$ exhibits three polymorphs depending on temperature: monoclinic phase is stable up to about $1170^{\circ} \mathrm{C}$. After this temperature, the conversion from the monoclinic phase to the tetragonal phase begins and the tetragonal phase is stable up to $2370{ }^{\circ} \mathrm{C}$. From this temperature to the melting temperature of $2680^{\circ} \mathrm{C}$, it is in the cubic phase. $[1,4]$. During the cooling process, transition from the tetragonal to monoclinic phase occurs. This transformation is very important because of resulting in a volumetric change of around 3\% to $5 \%$ and so, leads to cracks. To prevent this transformation and stabilize the zirconia, it is common to use stabilizers. The addition of stabilizers to $\mathrm{ZrO}_{2}$, lowers the temperature of polymorphic transformations, reduces the volume changes and blocks the transformation. With using stabilizers, it is possible to ensure the existence of high-temperature phases at room temperature too [4]. Different stabilizers, such as, $\mathrm{Al}_{2} \mathrm{O}_{3}, \mathrm{CaO}, \mathrm{CeO}_{2}, \mathrm{MgO}, \mathrm{SiO}_{2}$, $\mathrm{TiO}_{2}, \mathrm{Y}_{2} \mathrm{O}_{3}$ and even a combination of them, stabilize and keep stable the $\mathrm{ZrO}_{2}$ in the tetragonal and/or cubic forms at room temperature [5-7]. It is possible to produce materials consisting of only $\mathrm{t}-\mathrm{ZrO}_{2}$ or $\mathrm{c}-\mathrm{ZrO}_{2}$ or a mixture of these with $\mathrm{m}-\mathrm{ZrO}$ phases by adding different quantities of stabilizer. If less than sufficient stabilizing oxide is added, partially stabilized zirconia (PSZ) is obtained instead of fully stabilized zirconia. PSZ usually consists of two or more closely mixed phases. As a result of using stabilizers and obtaining fully or partially stabilized zirconia, achieve excellent mechanical properties such as bending strength, fracture toughness, hardness [8].

Although, zirconia exhibits better mechanical properties than other ceramics, but like all other ceramics, it is fragile and cannot be formed at room temperature. So, we want to increase the toughness of these materials. For this, some energy absorbing mechanisms such as transformation toughening and fiber reinforcement are used in ceramic matrices [1].

In the method of increasing fracture toughness with transformation toughness, it works on the principle of a phase transformation caused by tension, by reducing the driving force that propagates existing cracks in the material structure [1]. The best example of this is zirconia. Zirconia which is added to the ceramic main phase, plays an important role in increasing the fracture toughness and thus the bending strength with its tetragonal - monoclinic transformation toughening feature. With the discovery of the transformation toughening that occurs in zirconia, this material has found wide use. Because the main factor limiting the use of $\mathrm{ZrO}_{2}$ in advanced engineering applications was the low toughness of this material. Increasing the toughness property with transformation toughness has also increased the interest in zirconia. The volume increase of $3-5 \%$, which occurs with the tetragonal - monoclinic phase transformation in zirconia, prevents crack propagation and increases the toughness of the material and its resistance to fracture [9]. The $\mathrm{t}-\mathrm{m}$ transformation in zirconia can occur in different ways. For example: $\mathrm{t}-\mathrm{ZrO}_{2}$ can be free as a single particle or crystal; It can also be found in a compacted form in a matrix as a precipitate phase. Tetragonal zirconia particle size and the matrix in which the particles are compacted are the most important factors. A critical $\mathrm{t}-\mathrm{ZrO}_{2}$ grain size determine in $\mathrm{ZrO}_{2}$. If the grain size is below this critical size, there will be no transformation; above, the $\mathrm{t}-\mathrm{m}$ transformation occurs either continuously or as a result of applying a stress [10].

In the ceramic - ceramic mixed structure formation process, which is the other method of increasing the fracture toughness, the strength and toughness are increased by adding ceramic whiskers, fibers or particles to the main phase. This method is based on creating a physical barrier to the progressive crack. Having higher tensile strength than polycrystalline material, whiskers are a good barrier to propagation cracking. So, the fracture toughness of the submicrometric or nanocrystalline zirconia can be further increased by adding secondary phases into zirconia matrix, such as nanotubes, nanofibres or nanoplatelets [11]. During the last decades, the development of nanomaterials has offered a new alternative for reinforcing ceramics. Carbon nanotubes (CNTs) have attracted increasing attention as reinforcement because of their excellent properties. However, the CNTs are prone to reacting with an oxide matrix at high temperature, leading to the degradation in mechanical properties of CNTs and a limited reinforcing effect on the ceramics $[12,13]$. So, it is stated that incorporation of mullite which is another type of ceramic toughening method with its high temperature oxidation and corrosion resistance and the other superior properties, might be preferred [11]. In the literature, mullite $\left(3 \mathrm{Al}_{2} \mathrm{O}_{3} \cdot 2 \mathrm{SiO}_{2}\right)$ is defined as the unique stable intermediate crystalline phase of the $\mathrm{Al}_{2} \mathrm{O}_{3}-\mathrm{SiO}_{2}$ binary system, cost-friendly and exhibiting good refractory ability $[14,15]$. Mullite has received significant attention for technological applications due to its good properties such as high melting point, low coefficient of thermal expansion, high chemical stability, high creep resistance and sufficient hardness [16,17]. In summary, the fracture toughness of the submicron or nanocrystalline zirconia can be further improved by adding mullite being the secondary phase into the zirconia matrix and so, the other mechanical properties can be improved too [11]. In addition, the sintering temperature is also particularly important, because it affected the properties of ceramics through alteration of the microstructure and crystalline phases [18]. Studies continue on the effect of different sintering temperatures on the microstructure and mechanical properties of mullitezirconia ceramics.

In this study, mullite $\left(3 \mathrm{Al}_{2} \mathrm{O}_{3} .2 \mathrm{SiO}_{2}\right)$ and $11 \mathrm{~mol} \%$ calcia doped zirconia $\left(\mathrm{CaO}-\mathrm{ZrO}_{2}\right)$ ceramic powders were synthesized by conventional ceramic production processing route. Then, the effect of mullite additive on the properties of this mixture was investigated. The data obtained were presented in graphs and tables and their results were commented. 


\section{Material and Method}

Mullite and calcia doped zirconia ceramic powders were produced by conventional ceramic production processing route in this study. All precursory powder materials $\left(\mathrm{Al}_{2} \mathrm{O}_{3}, \mathrm{SiO}_{2}, \mathrm{CaO}\right.$ and $\mathrm{ZrO}_{2}$ ) used in the present work were purchased from Eczacıbaş1 Company, Alfa Aesar and Handan Yaxiang Chemicals Trading Co., Ltd (Eczacıbaşı Esan, Turkey; Alfa Aesar, United States of America and Handan Yaxiang Chemicals Trading Co., Ltd, China). The mixtures were prepared by mechanical alloying method in acetone environment with zirconia ball mill. The powders were dried in oven at $110^{\circ} \mathrm{C}$ for 24 hours before mixing. Mullite $\left(3 \mathrm{Al}_{2} \mathrm{O}_{3} .2 \mathrm{SiO}_{2}\right)$ and $11 \mathrm{~mol} \%$ calcia doped zirconia $(\mathrm{CaO}-$ $\mathrm{ZrO}_{2}$ ) ceramic powders were synthesized by reaction sintering from the powders made up of stoichiometric proportions of $\mathrm{Al}_{2} \mathrm{O}_{3}$, $\mathrm{SiO}_{2}, \mathrm{CaO}$ and $\mathrm{ZrO}_{2}$ powders after being homogenized in acetone environment in ball mills. Mullite $\left(3 \mathrm{Al}_{2} \mathrm{O}_{3} \cdot 2 \mathrm{SiO}_{2}\right)$ and $11 \mathrm{~mol} \%$ calcia doped zirconia $\left(\mathrm{CaO}-\mathrm{ZrO}_{2}\right)$ ceramic powders were synthesized in air at $1600{ }^{\circ} \mathrm{C}$ and $1300{ }^{\circ} \mathrm{C}$ for $3 \mathrm{~h}$ and $2 \mathrm{~h}$, respectively. Then, the ceramic phases formed were made ready to form ceramic - ceramic composites by crushing, grinding and sieving processes. Then 0 and $10 \%$ by weight mullite added calcia doped zirconia mixtures were prepared by powder metallurgy method (hereinafter these mixtures will be named CaZOM and CaZ10M respectively). The sample was coded as CaZ10M16005 (CaZ: Calcia doped zirconia; 10M: 10\% Mullite addition and 16005: $1600{ }^{\circ} \mathrm{C}$ sintering temperature and 5 hours sintering time). The prepared mixtures were wet milled with zirconia ball mill for $24 \mathrm{~h}$ and sieved. After drying, the powders were compacted to preforms of $56 \times 12 \times 10 \mathrm{~mm}$ by uniaxial pressing at $200 \mathrm{MPa}$. The green compacts were sintered at $1500-1600{ }^{\circ} \mathrm{C}$ for $1-5 \mathrm{~h}$ in air conditions using a heating rate of $5^{\circ} \mathrm{C} \mathrm{min}-1$ in a high temperature furnace (Protherm ${ }^{\mathrm{TM}}$ Furnace). Then, microstructure (SEM), phase analysis (XRD), mechanical (hardness, 3-point bending and wear) and physical properties (\% shrinkage, water absorption, porosity and density) tests were performed on the mullite added calcia doped zirconia ceramic composites.

The 3-point bending strength tests of the samples were performed on with a crosshead speed of $0.5 \mathrm{~mm} / \mathrm{min}$ in a Shimadzu brand tensile-compression device. Five measurements were made for each sample and average results were accepted as the strength values of the samples. The strength calculations were made with the formula:

$$
\sigma=3 / 2 * P^{*} L /\left(b^{*} h^{2}\right)
$$

(In (1) the letters mean that, P: maximum applied load, L: distance between supports, b: width, h: height).

The samples were polished on a velvet broadcloth using a 1 $\mu \mathrm{m}$ diamond solution after the 180, 320, 600, 1200 and 2500 grit sanding process, respectively. The diagonal field traces on the polished specimens were created using a square pyramid diamond tip with a $136^{\circ}$ apex angle and $1 \mathrm{~kg}$ load for 10 seconds on the Mitutoyo brand vickers hardness tester. When calculating the hardness values, five measurements were taken and the results were given as average [19-24]. Plint brand wear tester was used for the wear tests of ceramics. Steel discs were used as wear disc. Wear tests were performed on each sample at $400 \mathrm{rpm}$ rate, 5, 10 and $15 \mathrm{~min}$ wear durations and $100 \mathrm{~N}$ force. First, the specimen was measured with a precision scale of $0.0001 \mathrm{~g}$, and the amount of wear was determined by measuring again after the specified wear time [22,23]. To determine the phases, X-ray powder diffractometer with $\mathrm{Cu} \mathrm{K} \alpha$ radiation (Bruker AXS D8 Advance;
$20 \mathrm{kV}-60 \mathrm{kV}, 6 \mathrm{~mA}-80 \mathrm{~mA}$ and $\theta=10^{\circ}-90^{\circ}, 0.002^{\circ}$ ) was used. The phase analysis of the XRD patterns was determined using the Pananalitical X'Pert High Score program. The microstructural characterization of the samples was made with the Mira3XMU FE-SEM (Tescan, Czech Republic) brand scanning electron microscope (SEM) with an energy dispersion spectrum (EDS). The data obtained were presented in graphs and tables and their comments were made.

\section{Results and Discussion}

Specified to sintered samples: Physical tests (total shrinkage, water absorption, porosity and density tests), mechanical tests (hardness, 3-point bending and wear), scanning electron microscopy (SEM) for EDS analysis and XRD for phase analysis. Measurements and calculations were made 5 times replicates, and their arithmetic averages were obtained.

Table 1. Physical test results of CaZOM and CaZ10M samples

\begin{tabular}{lccccc}
\hline Samples & $\begin{array}{c}\text { Bulk } \\
\text { dens. } \\
\text { g/cm }\end{array}$ & $\begin{array}{c}\text { Rel. } \\
\text { dens. } \\
(\mathbf{\%})\end{array}$ & $\begin{array}{c}\text { Water } \\
\text { Absorp. } \\
\mathbf{( \% )}\end{array}$ & $\begin{array}{c}\text { Por. } \\
\mathbf{( \% )}\end{array}$ & $\begin{array}{c}\text { Shir. } \\
\mathbf{( \% )}\end{array}$ \\
\hline CaZ00M15001 & 4,77 & 86,77 & 3,41 & 13,23 & 9,79 \\
CaZ00M15005 & 5,16 & 93,89 & 1,75 & 6,11 & 12,20 \\
CaZ00M16001 & 5,17 & 94,04 & 1,20 & 5,96 & 12,43 \\
CaZ00M16005 & 5,26 & 95,67 & 0,36 & 4,33 & 12,76 \\
CaZ10M15001 & 4,72 & 90,89 & 1,33 & 9,11 & 9,52 \\
CaZ10M15005 & 4,74 & 91,28 & 1,02 & 8,72 & 9,76 \\
CaZ10M16001 & 4,71 & 90,70 & 1,41 & 9,30 & 9,47 \\
CaZ10M16005 & 4,58 & 88,19 & 1,79 & 11,81 & 8,65 \\
\hline
\end{tabular}

The results of physical measurements (water absorption, bulk density, porosity and shrinkage) are given in Table 1, and also shown Figure 1. In Figure 1, the relative density values were taken at the rate of $1 / 3$ of the actual values for the graph to be more understandable.

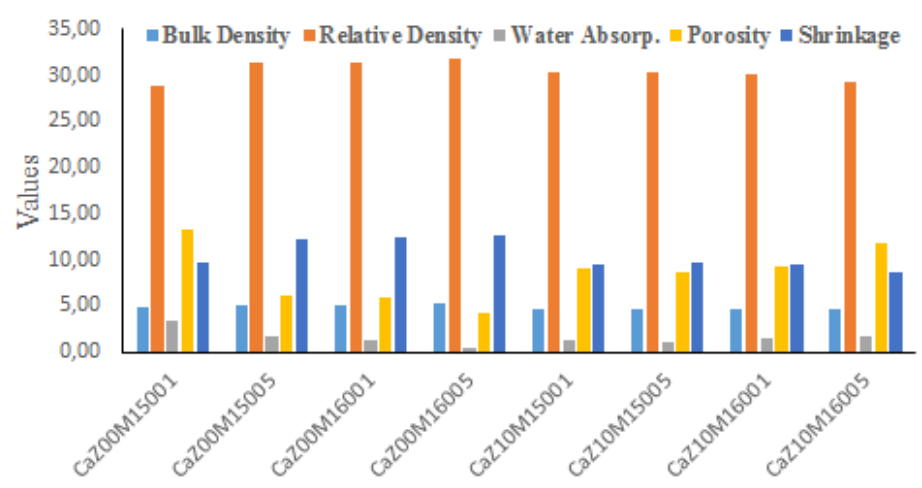

Figure 1. Physical test results graph of CaZ0M and CaZ10M samples

From the physical test results, it is found that the shrinkage values increased with increasing sintering temperature and time in mullite-free samples, and accordingly, the water absorption and porosity values decreased; it is seen that the experimental density and relative density values increase. In the mullite added samples, while the experimental density, relative density and shrinkage values increased in 1500 samples; these values decrease in 1600 samples. We think that this is a result of the defects and phase 
changes occurring in the microstructure at $1600{ }^{\circ} \mathrm{C}$ temperature. In addition, it is seen that the shrinkage, experimental density and relative density values are lower in mullite added samples, and the water absorption and porosity values are higher.

Table 2, Figure 2 and Figure 3 indicated hardness and 3-point bending strength values of CaZ0M and CaZ10M samples.

From the Table 2 and Figure 2, when the hardness test results are examined, it is seen that the hardness values increase with increasing sintering temperature and time in mullite-free samples. It is seen that the hardness values of 1600 samples decreased in mullite added samples. We think that this is related to the large pores formed in the microstructure and in addition possible phase changes. In addition, it is seen that the hardness values of the mullite added samples are lower.

Table 2. Hardness and 3-point bending strength values of CaZ0M and CaZ10M samples

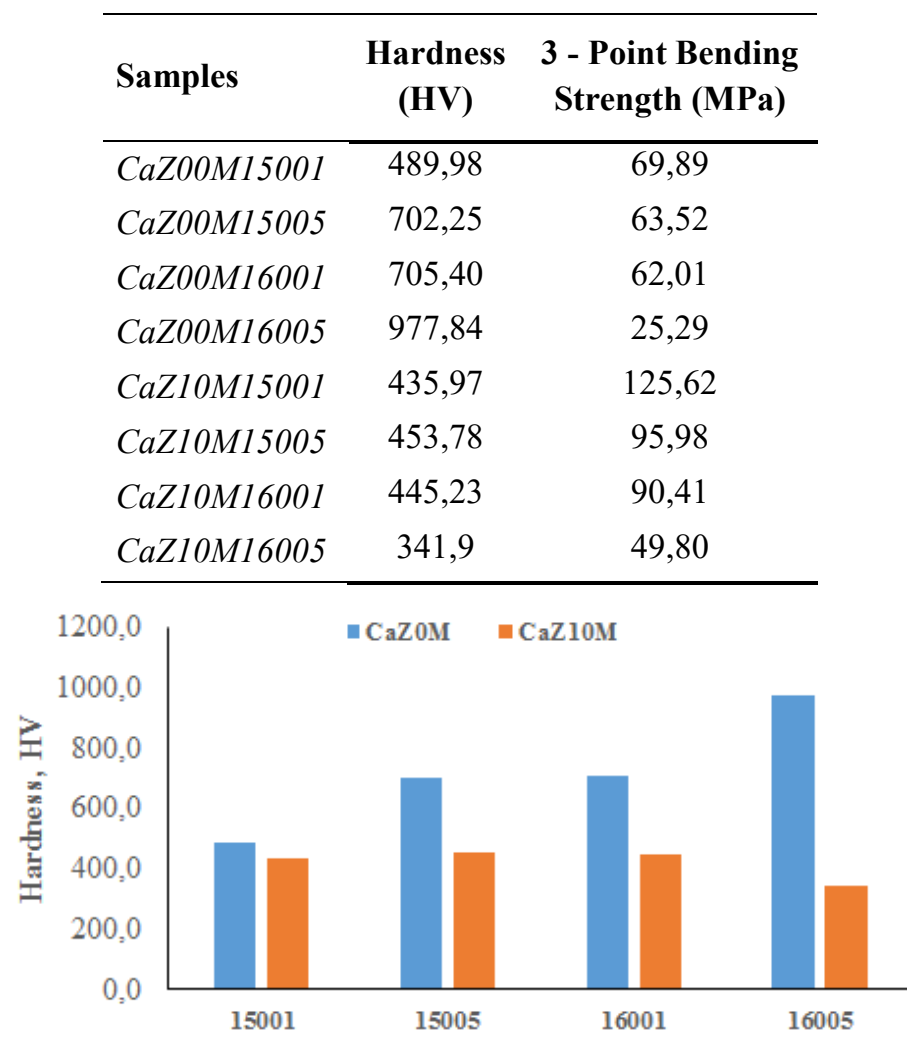

Figure 2. Hardness graph of samples

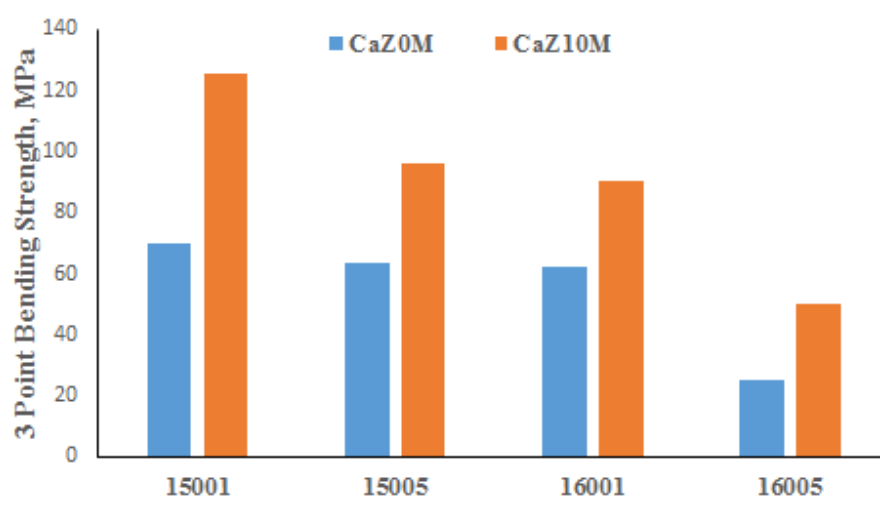

Figure 3. 3-Point bending strength graph of samples

The bending test results show that that three - point bending strength values decrease with increasing sintering temperature and time in all samples. In addition, it is seen that the three-point bending strength values of the mullite added samples are higher. We think that this is a result of the differences in the microstructure and possible phase changes depending on the sintering temperature, sintering time and mullite additive.

Plint brand wear tester was used for the wear tests of ceramics. Steel disc is used as wear disc. Wear tests were performed on each sample at 5,10 and 15 min wear durations and $100 \mathrm{~N}$ force (400 rpm constant speed). First, the specimen was measured with a precision scale of $0.0001 \mathrm{~g}$, and the amount of wear was determined by measuring again after the specified wear time. The wear results are shown in Table 3 and Figure 4.

Table 3. Wear Results of CaZ0M and CaZ10M Samples

\begin{tabular}{lccc}
\hline \multirow{2}{*}{ Samples } & \multicolumn{3}{c}{ Wear Volume $\left(\mathbf{m m}^{\mathbf{3}}\right) \mathbf{, 1 0 0} \mathbf{~}$} \\
\cline { 2 - 4 } & $\mathbf{5} \mathbf{~ m i n .}$ & $\mathbf{1 0} \mathbf{~ m i n}$. & $\mathbf{1 5} \mathbf{~ m i n}$. \\
\hline CaZ00M15001 & 0,658 & 2,224 & 3,978 \\
CaZ00M15005 & 0,616 & 2,232 & 3,421 \\
CaZ00M16001 & 0,605 & 2,199 & 3,298 \\
CaZ00M16005 & 1,855 & 4,114 & 9,443 \\
CaZ10M15001 & 0,868 & 1,745 & 2,501 \\
CaZ10M15005 & 0,802 & 1,296 & 1,977 \\
CaZ10M16001 & 0,774 & 1,416 & 2,258 \\
CaZ10M16005 & 0,881 & 2,109 & 2,766 \\
\hline
\end{tabular}

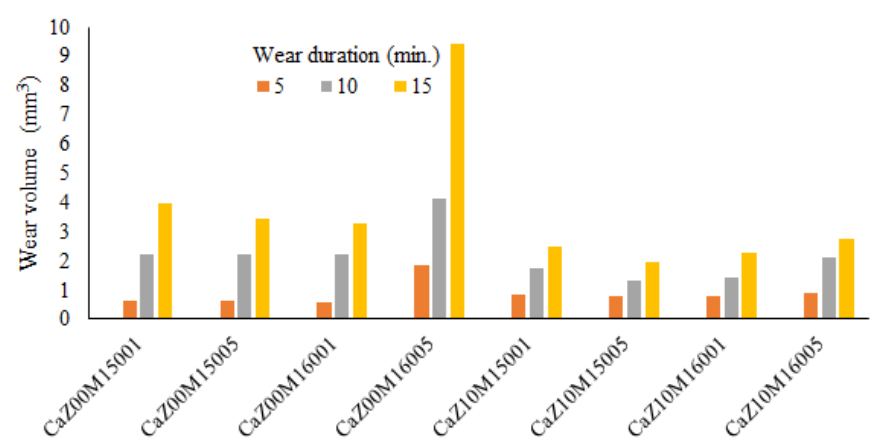

Figure 4. Wear test results graph of samples

When we look at the wear test results, we can say that the results vary depending on the hardness, bending strength and wear time of the samples. In general, as the wear time increased, the amount of wear of the samples also increased. The wear resistance of the samples with high hardness and bending strength is higher and the mullite additive improves the wear resistance of these samples. Although adhesive type wear was observed in the samples in general, it was observed that with the increase in the wear time in some samples, cracks occur on the worn surface and very small pieces break off and cause abrasive wear too. Although it has especially high hardness, the high amount of wear seen in the CaZ00M16005 sample is due to the brittle and easily breakable structure of the sample, and its three-point bending strength is very low compared to the other samples.

The phase changes in the sample structure depending on the sintering temperature and time of CaZ0M and CaZ10M samples were analyzed and the basic phases that emerged in the structure were shown in Figure 5 and Figure 6. 


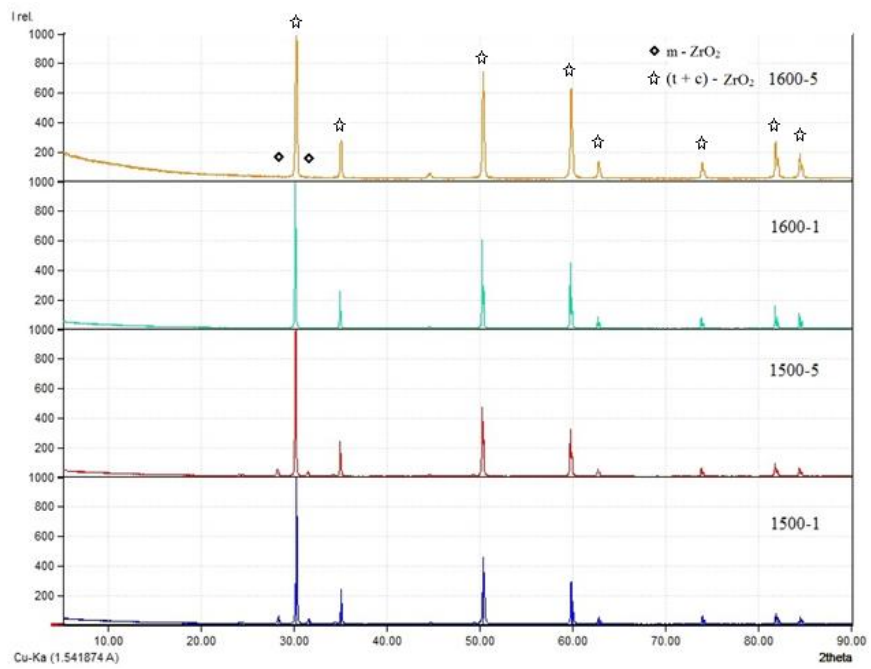

Figure 5. XRD patterns of CaZOM samples

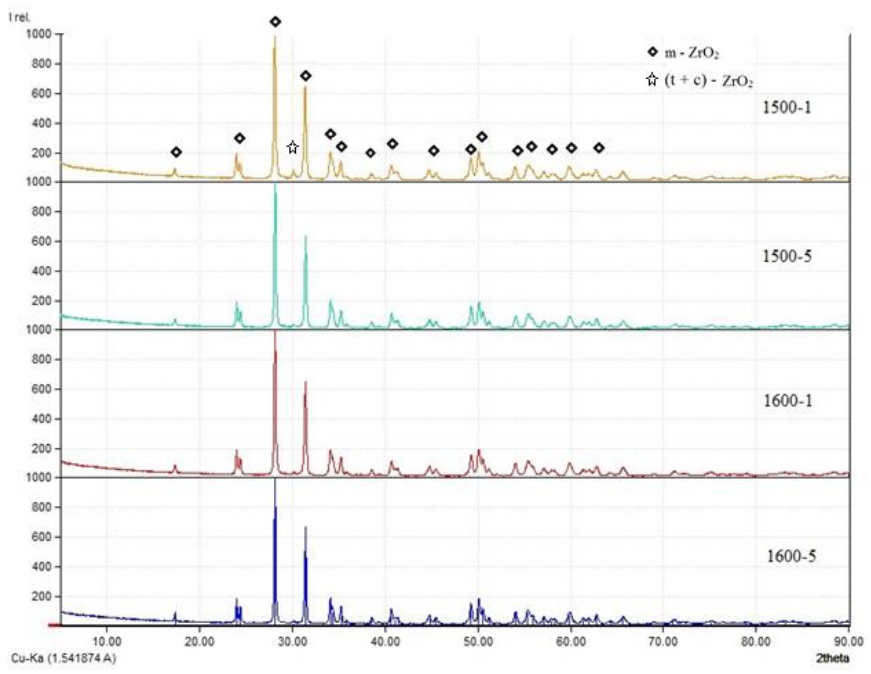

Figure 6. XRD patterns of CaZ10M samples

The microstructure image of CaZ00M16005 and CaZ10M16005 samples is given in Figure 7.
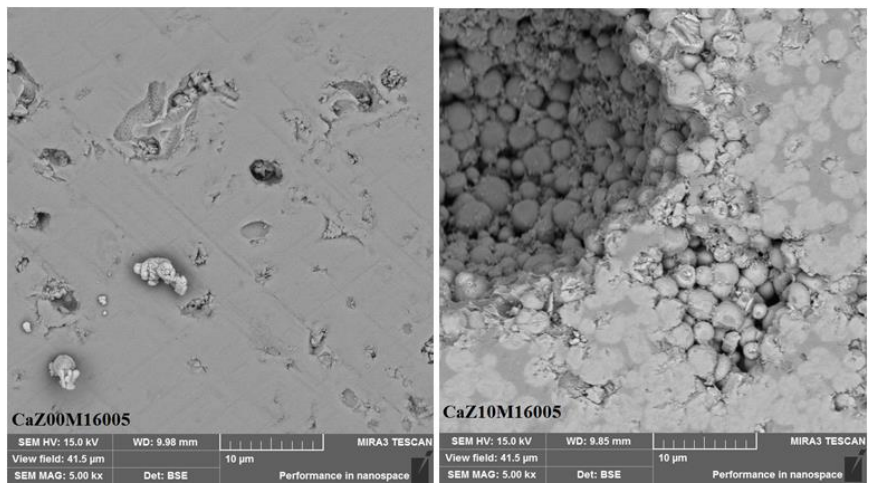

Figure 7. SEM images of CaZ00M16005 and CaZ10M16005 samples

Elemental analyzes of CaZ00M16005 and CaZ10M16005 samples with EDS are given in Figure 8 and Figure 9.

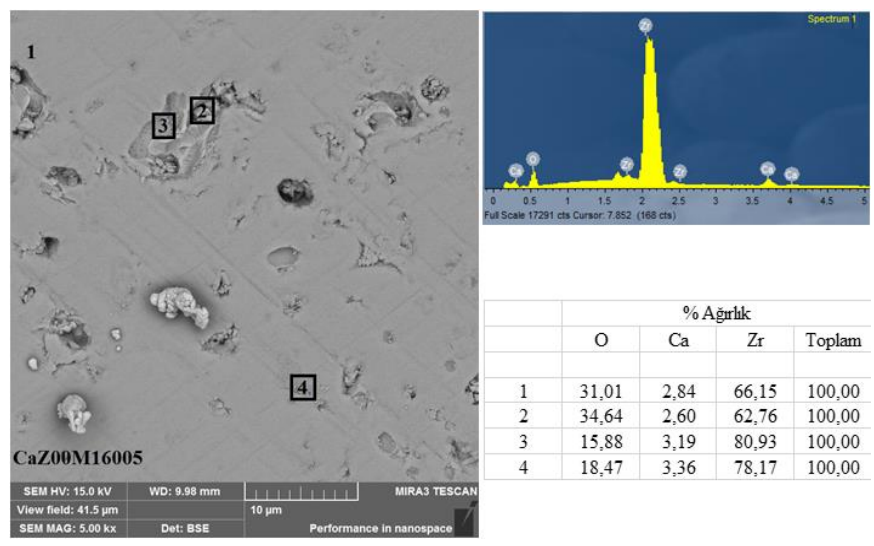

Figure 8. EDS analyses of CaZ00M16005 samples
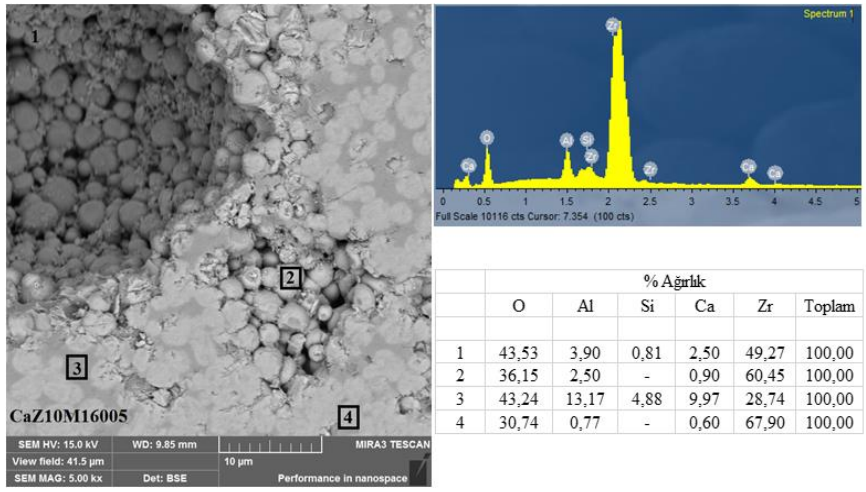

Figure 9. EDS analyses of CaZ10M16005 samples

Nath et al [25] obtained partially stabilized zirconia with 8 $\mathrm{mol} \% \mathrm{CaO}$ and fully stabilized zirconia with $16 \mathrm{~mol} \% \mathrm{CaO}$ in their study. For PSZ, the $\mathrm{c}-\mathrm{ZrO}_{2}$ phase increased at temperatures of 1550 and $1585^{\circ} \mathrm{C}$; They stated that the $\mathrm{t}-\mathrm{ZrO}_{2}$ phase decreased to a negligible extent. Although the density values of PSZ materials are higher than FSZ materials, the hardness values of single-phase c- $\mathrm{ZrO}_{2} \mathrm{FSZ}$ materials are higher because the $\mathrm{m}-\mathrm{ZrO}_{2}$ phase is softer than the $\mathrm{t}-\mathrm{ZrO}_{2}$ and $\mathrm{c}-\mathrm{ZrO}_{2}$ phases.

Accordingly, as can be seen from the XRD graphs given in Figure 5, while there is a small amount of $\mathrm{m}-\mathrm{ZrO}_{2}$ phase in the mullite-free 1500 samples; In 1600 samples, the structure completely transformed into the $\mathrm{c}-\mathrm{ZrO}_{2}$ phase. As the $\mathrm{c}-\mathrm{ZrO}_{2}$ phase increases, the amount of $\mathrm{t}-\mathrm{ZrO}_{2}$ phase in the structure decreases, and as a result, the fracture toughness and bending strength decrease as the $\mathrm{t}-\mathrm{m}$ transformation toughness decreases [26].

Therefore, since the $\mathrm{c}-\mathrm{ZrO}_{2}$ phase increases significantly in the 1600-5 samples, the hardness will increase, but the bending strength will take the lowest value, confirming the values we obtained.

Kumar et al [27] produced mullite-zirconia ceramics using 0 $-12 \mathrm{~mol} \% \mathrm{CaO}$ with 2 hours sintering at temperatures of 1450 $1600{ }^{\circ} \mathrm{C}$. It has been stated that $\mathrm{CaO}$ increases the mechanical properties by forming the $\mathrm{t}-\mathrm{ZrO}_{2}$ phase. They stated that the density values decreased from 1500 to 1600 with $12 \mathrm{~mol} \% \mathrm{CaO}$ and the highest density value was obtained at $1500{ }^{\circ} \mathrm{C}$.

Chandra et al [28] produced mullite-zirconia ceramics using $2.5-10 \%$ by weight of $\mathrm{CaO}$ by sintering for $3,4,5$ hours at temperatures of $1450-1550{ }^{\circ} \mathrm{C}$. It has been stated that the mullite phase is not present in the structure due to the formation of a small 
amount of different phases in the samples with $10 \% \mathrm{CaO}$ by weight. It is stated that the wear resistance is worse due to the absence of mullite formation. It was also stated that the effect of $\mathrm{CaO}$ on the $\mathrm{m}-\mathrm{ZrO}_{2}$ phase crystallite size is not regular.

In this direction, as can be seen from the $\mathrm{XRD}$ graphs given in Figure 6, it is seen that there is no mullite phase in the structure of the mullite added samples, and this result confirms the work of Chandra et al.

In our study, while $\mathrm{t}-\mathrm{ZrO}_{2}$ phase was observed in XRD 15001 in mullite-doped samples, this phase decreased in 1500-5, and it almost completely turned into $\mathrm{m}-\mathrm{ZrO}_{2}$ phase in 1600 samples. For this reason, the highest value of bending strength is in the 1500-1 sample. The lowest flexural strength in the 1600-5 samples is due to the decrease in $\mathrm{t}-\mathrm{m}$ transformation toughness as a result of the decrease in the $\mathrm{t}-\mathrm{ZrO}_{2}$ phase and also due to grain coarsening. Our density values also yielded results in line with the work of Kumar et al.

Also in the SEM image given in Figure 7, the presence of large pores in the mullite added sample confirms that the density has decreased. As can be seen from the SEM image given in Figure 7, the amount and size of the pores on the surface increased significantly with the addition of mullite. It can be predicted that this situation will have a negative effect on the hardness values of the samples and decrease the hardness value of the mullite added sample. As a matter of fact, in the experimental results, the hardness value of the CaZ10M16005 sample was found to be lower than the hardness value of the CaZ00M16005 sample.

According to the EDS analyzes given in Figure 8 and Figure 9, the evaluation of the EDS analysis results on the CaZ00M16005 and CaZ10M16005 samples was made from general (1) and parts $2,3,4$. It has been observed that the results of the EDS elemental analysis made from the general field survey (1) and other parts are compatible with the contribution rates and $\mathrm{XRD}$ results made to the samples.

\section{Conclusions and Recommendations}

In this study, utilization of mullite in the manufacturing of calcia doped zirconia was investigated and it has been evaluated the effect of $\mathrm{CaO}$ and mullite contribution to $\mathrm{ZrO}_{2}$ main matrix.

In all samples, it was observed that 3 - point bending strength values decreased with increasing sintering temperature and time. With increasing sintering temperature and time, shrinkage, experimental and relative density, hardness values and wear resistance of the CaZ0M coded mullite-free samples except for the 1600-5 sample increased; the water absorption and porosity values decreased. Although it has especially high hardness, the high amount of wear seen in the CaZ00M16005 sample is due to the brittle and easily breakable structure of the sample, and its three-point bending strength is very low compared to the other samples. The low flexural strength value of this sample despite its high hardness was explained by XRD phase analysis and the work of Nath et al. [25]. Accordingly, as the sintering temperature and time increase, the $\mathrm{c}-\mathrm{ZrO}_{2}$ phase increases significantly, especially in 1600-5 samples, and the hardness will also increase; However, it was stated that while the $\mathrm{c}-\mathrm{ZrO}_{2}$ phase increased, the amount of $\mathrm{t}-\mathrm{ZrO}_{2}$ phase in the structure was decreasing, and as a result, the $\mathrm{t}-\mathrm{m}$ transformation toughening was reduced, so the bending strength got the lowest value.
In CaZ10M coded mullite added samples, while shrinkage, experimental and relative density, hardness values and wear resistance increased in 1500 samples; in the 1600 samples these values fall in line with the results obtained by Kumar et al [27]. We think this is a result of the differences in the microstructure and phase changes at $1600{ }^{\circ} \mathrm{C}$ temperature. While $\mathrm{t}-\mathrm{ZrO}_{2}$ phase was observed in XRD 1500-1 in mullite-doped samples, this phase decreased in 1500-5, and it almost completely transformed into $\mathrm{m}-\mathrm{ZrO}_{2}$ phase in 1600 samples. For this reason, the highest value of bending strength is in the 1500-1 sample. The lowest flexural strength in the 1600-5 samples is due to the decrease in t$\mathrm{m}$ transformation toughness as a result of the decrease in the $\mathrm{t}$ $\mathrm{ZrO}_{2}$ phase and also due to grain coarsening.

While the shrinkage, experimental density, relative density, and hardness values of the samples with mullite additives decreased in general compared to the samples without additives; It was observed that water absorption, porosity and three-point flexural strength values and wear resistance increased. While $\mathrm{m}$ $\mathrm{ZrO}_{2}, \mathrm{t}-\mathrm{ZrO}_{2}$ and $\mathrm{c}-\mathrm{ZrO}_{2}$ phases were detected in the samples, mullite phase could not be detected in the phase analysis of the samples with mullite additives, and this result compatible with the work of Chandra et al [28].

\section{Acknowledge}

This work is supported by the Scientific Research Project Fund of Sivas Cumhuriyet University under the project number M-767. Authors would like to acknowledge Scientific Research Project Fund of Sivas Cumhuriyet University.

\section{References}

[1] Boyraz, T. (2008). An investigation on physical and electrical properties of $\mathrm{CaO} / \mathrm{MgO}$-stabilized zirconia ceramics formed with different methods. Istanbul Technical University / Graduate School of Natural and Applied Sciences, (Doctoral dissertation). 150p.

[2] Pekdemir, A.D. (2018). Preparation and characterization of boron carbide at low-temperature from boric acid and polyols. Ankara University / Graduate School of Natural and Applied Sciences, (Doctoral dissertation). 178p

[3] Ceylan, A. (2006). The production of functionally graded SiAlON ceramics by tape casting method. Anadolu University / Graduate School of Natural and Applied Sciences, (Doctoral dissertation). 204p.

[4] Abi, C.B. (2009). An investigation on fracture toughness of traditional and technical ceramics. Afyon Kocatepe University / Graduate School of Natural and Applied Sciences, (Doctoral dissertation). 194p.

[5] Hafızoğlu M. A., Boyraz, T. and Akkuş, A. (2021). Fabrication, characterization and wear properties of mullite reinforced silica-doped zirconia ceramic composites. 4. International Conference on Materials Science, Mechanical and Automotive Engineerings and Technology (IMSMATEC'21).

[6] Hafızoğlu M. A., Akkuş, A. and Boyraz, T. (2021). Fabrication, characterization and wear properties of mullite reinforced $\mathrm{A} 12 \mathrm{O} 3$-doped $\mathrm{ZrO} 2$ ceramic composites. Global Conference on Engineering Research (GLOBCER'21).

[7] Hafizoğlu M. A., Boyraz, T. and Akkuş, A. (2021). Fabrication and characterization of mullite reinforced $\mathrm{TiO} 2$ added $\mathrm{ZrO} 2$ 
ceramics. International Joint Science Congress of Materials and Polymers (ISCMP'21).

[8] Cutler, R. A., Reynolds, J. R. and Jones, A. (1992). Sintering and characterization of polycrystalline monoclinic, tetragonal, and cubic zirconia. Journal of the American Ceramic Society, 75(8), 2173-2183.

[9] Boyacıoğlu, T. (2007). Improvement of room temperature mechanical properties of various amount of metal oxide doping cubic zirconia (c-ZrO2) used as electrolyte material for solid oxide fuel cells. Gazi University / Graduate School of Natural and Applied Sciences, (Master's thesis). 123p.

[10] Boyraz, T. (1998). Dental porcelain powders. Sakarya University / Graduate School of Natural and Applied Sciences, (Master's thesis). 131p.

[11] Liu, P. F., Li, Z., Xiao, P. et al. (2018). Microstructure and mechanical properties of in-situ grown mullite toughened $3 \mathrm{Y}$ TZP zirconia ceramics fabricated by gelcasting. Ceramics International, 44(2), 1394-1403.

[12] Eichler, J., Rödel, J. et al. (2007). Effect of grain size on mechanical properties of submicrometer 3Y-TZP: fracture strength and hydrothermal degradation. Journal of the American Ceramic Society, 90(9), 2830-2836.

[13] Sun, J., Gao, L., Iwasa, M., Nakayama, T. and Niihara, K. (2005). Failure investigation of carbon nanotube/3Y-TZP nanocomposites. Ceramics International, 31(8), 1131-1134.

[14] El Ouatib, R., Guillemet, S., Durand, B. et al. (2005). Reactivity of aluminum sulfate and silica in molten alkalimetal sulfates in order to prepare mullite. Journal of the European Ceramic Society, 25(1), 73-80.

[15] Kucuk, I. and Boyraz, T. (2019). Structural and mechanical characterization of mullite and aluminium titanate reinforced yttria stabilized zirconia ceramic composites. Journal of Ceramic Processing Research, 20(1), 73-79.

[16] Kumar, P., Nath, M. et al. (2015). Enhancement of thermal shock resistance of reaction sintered mullite-zirconia composites in the presence of lanthanum oxide. Materials Characterization, 101, 34-39.

[17] Roy, J., Das, S. and Maitra, S. (2015). Solgel-processed mullite coating - a review. International Journal of Applied Ceramic Technology, 12, E71-E77.

[18] Denry, I. and Kelly, J. R. (2008). State of the art of zirconia for dental applications. Dental materials, 24(3), 299-307.

[19] Çitak, E. and Boyraz, T. (2014). Microstructural characterization and thermal properties of aluminium titanate/YSZ Ceramics. Acta Physica Polonica A, 125(2), 465-468.

[20] Önen, U. and Boyraz, T. (2014). Microstructural characterization and thermal properties of aluminium titanate/spinel ceramic matrix composites. Acta Phys. Pol. A, 125(2), 488-490.

[21] Sacli, M., Onen, U. and Boyraz, T. (2015). Microstructural characterization and thermal properties of aluminium titanate/porcelain ceramic matrix composites. Acta Physica Polonica A, 127(4), 1133-1135.

[22] Boyraz, T. and Akkuş, A. (2021). Investigation of wear properties of mullite and aluminium titanate added porcelain ceramics, Journal of Ceramic Processing Research. Vol. 22, No. 2, pp. 226-231.

[23] Akkus, A. and Boyraz, T. (2018). Investigation of wear properties of $\mathrm{CaO}, \mathrm{MgO}$ added stabilized zirconia ceramics produced by different pressing methods. J Ceram Process Res, 19(3), 249-52.
[24] Kucuk, I., Boyraz, T. et al. (2018). Thermomechanical properties of aluminium titanate (A12TiO5)-reinforced forsterite (Mg2SiO4) ceramic composites. Ceramics International, 44(7), 8277-8282.

[25] Nath, S., Sinha, N., \& Basu, B. (2008). Microstructure, mechanical and tribological properties of microwave sintered calcia-doped zirconia for biomedical applications. Ceramics International, 34(6), 1509-1520.

[26] Yazıc1, E. G. (2013). Production and characterization of $\mathrm{MgO}$ partially stabilized zirconia dental ceramics. Afyon Kocatepe University / Graduate School of Natural and Applied Sciences, (Master's thesis). 127p.

[27] Kumar, P., Nath, M., Ghosh, A., \& Tripathi, H. S. (2016). Thermo-mechanical properties of mullite-zirconia composites derived from reaction sintering of zircon and sillimanite beach sand: Effect of CaO. Transactions of Nonferrous Metals Society of China, 26(9), 2397-2403.

[28] Chandra, D., Das, G., \& Maitra, S. (2015). Comparison of the Role of $\mathrm{Mg} \mathrm{O}$ and $\mathrm{C} \mathrm{a} \mathrm{O}$ Additives on the Microstructures of Reaction-Sintered Zirconia-Mullite Composite. International Journal of Applied Ceramic Technology, 12(4), 771-782. 